\title{
RESENHA DE “INTRODUÇÃO ÀS CIÊNCIAS DA LINGUAGEM: DISCURSO E TEXTUALIDADE” [ORLANDI, E.P.; LAGAZZI- RODRIGUES, S. (ORGS.) - CAMPINAS, SP: PONTES EDITORES, 2006]
}

\author{
Silmara Cristina Dela-Silva*
}

Apresentar um panorama geral sobre os estudos do texto e do discurso nas teorias da linguagem é o objetivo da obra Discurso e Textualidade, organizada pelas analistas de discurso Eni P. Orlandi e Suzy Lagazzi-Rodrigues. Segundo volume da coleção Introdução às Ciências da Linguagem, a obra soma-se aos títulos A palavra e a frase e Linguagem, história e conhecimento com o propósito de oferecer uma introdução aos estudos da linguagem, direcionada aos interessados em geral no tema língua/linguagem. Ao reunir artigos de professores e pesquisadores conceituados em suas áreas de atuação, Discurso e Textualidade possibilita conhecer a história dos estudos do texto e do discurso e refletir sobre a situação de suas teorias na atualidade.

Compreendido como "efeito de sentidos entre locutores" (PÊCHEUX, 1997), o discurso é o tema do primeiro capítulo da obra, redigido por Eni P. Orlandi. Em "Análise de discurso", Orlandi reúne os principais conceitos que compõem o dispositivo teórico desta disciplina de entremeio, iniciada na França, no final da década de 1960. Em seu percurso, oferece um panorama dos estudos atuais realizados a partir da perspectiva discursiva de análise, que constituem o que denomina uma "escola brasileira de análise de discurso" (ORLANDI, 2002). Ao apresentar conceitos caros à história e à prática da análise de discurso dentre eles, as noções de sujeito, condições de produção, memória discursiva, formação discursiva e interdiscurso -, Orlandi trata do

\footnotetext{
* Professora do Instituto Municipal de Ensino Superior de Catanduva (IMES). Doutora em Linguística. E-mail: < silmara.dela@uol.com.br >.
} 


\section{8}

movimento dos sentidos, das suas relações com o político e da opacidade da linguagem, questões que permeiam as práticas dos analistas de discurso.

No âmbito dos estudos sobre o texto, Freda Indursky, no segundo capítulo intitulado " $\mathrm{O}$ texto nos estudos da linguagem: especificidades e limites", centra a sua reflexão na categoria texto, observando-a a partir de quatro perspectivas: da linguística textual, da teoria da enunciação, da teoria semiótica e da análise de discurso. Com isso, o capítulo oferece ao leitor um percurso histórico e analítico sobre o texto nas ciências da linguagem, que extrapola a apresentação dos conceitos correntes de texto.

A questão “o que é um texto?”, posta em suspenso no segundo capítulo, a partir da análise da categoria texto, também é o ponto de partida para o estudo "Texto e autoria", de Suzy Lagazzi-Rodrigues, e que dá continuidade à obra. Ao considerar a incompletude constitutiva da linguagem, os seus equívocos e a sua opacidade, a autora propõe reflexões sobre o processo de interpretação e produção de textos, e o papel da autoria na textualidade. Com base na noção de autoria de Foucault e em sua relação com o discurso e os processos de produção de sentidos, proposta por Orlandi (1996), Lagazzi-Rodrigues alinha-se aos estudos discursivos que pensam a autoria como um princípio da unidade textual. As reflexões sobre texto e autoria contemplam ainda discussões sobre o que a autora define como "aprendizado da autoria como uma prática no processo de textualidade", um aprendizado que ocorre na escola, mas também no cotidiano, nas práticas de linguagem dos sujeitos.

O estudo dos processos de significação também é contemplado no quarto capítulo da obra, intitulado "Semiótica e semiologia", de Carlos Vogt. Em seu percurso de apresentação das tendências de estudos em semiótica e semiologia, e a sua relação com a linguística, Vogt traça um panorama histórico das duas linhas fundamentais de constituição da semiótica e da semiologia, que têm como marco os estudos de Saussure (1977), e do filósofo Charles Sanders Peirce. Em seu trabalho, Vogt aborda historicamente o desenvolvimento da semiótica e da semiologia em suas duas vertentes, em um percurso que permite a compreensão das distinções entre as noções de signo, por exemplo, em Saussure e em Peirce. Com base em exemplos, o texto oferece uma visão geral das questões de interesse na área, como as relações lógicas e as estruturas 
semióticas profundas, e propõe reflexões sobre as relações da semiótica com a ciência de modo geral.

Um panorama histórico semelhante ao exposto por Vogt ao apresentar a semiótica e a semiologia é oferecido ao leitor, no capítulo seguinte, por Evanildo Bechara, que trata da filologia nos estudos da linguagem. Em seu percurso, Bechara apresenta um histórico dos estudos filológicos dividido em quatro períodos: na antiguidade, na idade média, nos tempos modernos, com o renascimento da filologia, e o que denomina a passagem da "filologia à ciência histórica dos tempos antigos". Além deste percurso histórico detalhado, que aponta a relação inicial entre os estudos filológicos e a filosofia e, posteriormente, o desenvolvimento das demais ciências e o interesse pelas línguas, o autor mostra a relação entre a filologia e o surgimento da linguística, e propõe a reflexão sobre o papel da filologia na produção textual e nos estudos da linguagem.

A reflexão sobre o texto e o discurso nos estudos da linguagem é concluída com o capítulo sobre "Retórica e argumentação", por Mónica Zoppi-Fontana. Compreendida inicialmente "enquanto operação linguageira", a argumentação é especificada no decorrer de seu trabalho como "uma função da linguagem", "uma dimensão da língua" e como "um fato de discurso". Zoppi-Fontana adota como ponto de partida para a sua reflexão práticas cotidianas de linguagem, em que se colocam a necessidade de "argumentar" como parte das relações humanas, para apresentar o percurso dos estudos em seus diferentes enfoques. A autora trata desde os estudos da retórica antiga, como os pensamentos dos sofistas e de Aristóteles, até as tradições de estudos da nova retórica e da argumentação, a partir da década de 1950. Nesta perspectiva, mostra os principais conceitos da teoria da argumentação na língua, desenvolvida por Ducrot e Anscombre, a partir da década de 1970, e que sustenta-se na concepção de que a "argumentação está inscrita estruturalmente na língua, especificamente no léxico". Servindo-se de exemplos correntes, a autora oferece ainda uma visão atual dos estudos de semântica argumentativa no contexto brasileiro.

Embora não seja a primeira coletânea a fornecer um panorama geral dos estudos sobre língua/linguagem lançada no mercado editorial brasileiro nos últimos anos, Introdução às Ciências da Linguagem, em seus três volumes, diferencia-se das demais em sua organização, pelo material 
de apoio que fornece aos seus leitores e pela sua amplitude temática. Quanto à organização, os volumes apresentam capítulos elaborados para a abordagem de temas pertinentes aos estudos sobre língua/linguagem e não necessariamente centrados em um percurso histórico e nos conceitos fundamentais de uma corrente teórica específica. No caso particular do volume Discurso e Textualidade, os capítulos dois e três, dedicados respectivamente ao texto nos estudos da linguagem e à relação entre texto e autoria, são exemplos deste novo olhar. Para além dos limites de uma perspectiva teórica, o conceito de texto é abordado em seu percurso histórico, em diferentes teorias e em suas relações com as práticas de linguagem e os sujeitos.

Um outro diferencial da coleção está no material de apoio que apresenta aos leitores ao final de cada capítulo, subdividido em "Pontos a reter", "Para refletir" e "Leituras recomendadas". Na seção "Pontos a reter", os autores apresentam um resumo dos pontos essenciais para a compreensão do estudo desenvolvido, permitindo ao leitor, sobretudo aos iniciantes na área de conhecimento, uma seleção dos conceitos novos e das ideias propostas no capítulo. A segunda seção, "Para refletir", reúne questões para a reflexão sobre a leitura realizada, que servem como apoio à compreensão das teorias e dos conceitos apresentados, e se constituem em um material interessante para o docente, nos trabalhos com os textos teóricos em sala de aula. A seção "Leituras recomendadas", por sua vez, é composta por uma bibliografia comentada sobre o conteúdo abordado. Ao reunir sugestões de leitura e obras básicas das principais perspectivas teóricas apresentadas nos capítulos, as sugestões de leitura possibilitam a ampliação das pesquisas sobre o tema, de acordo com as necessidades de estudo dos leitores.

Contudo, o grande mérito da obra está na visão plural dos conceitos de texto e discurso que apresenta. Em seus três volumes, a coleção inclui perspectivas teóricas que não são usualmente agrupadas no campo dos estudos linguísticos. Nesta decisão editorial, prevalece o deslocamento de um pensar disciplinas específicas para uma proposta de se compreender os estudos sobre língua/linguagem no âmbito de um conjunto de disciplinas, o das Ciências da Linguagem. Esse deslocamento permite direcionar o olhar mais para as fronteiras entre essas disciplinas do que para as suas diferenças históricas. 


\section{REFERÊNCIAS}

ORLANDI, E.P. A análise de discurso e seus entremeios: notas sobre a sua história no Brasil. Cadernos de Estudos Linguísticos, Campinas, n. 42, p. 21 40, jan./jun. 2002.

Interpretação: autoria, leitura e efeitos do trabalho simbólico.

Petrópolis, RJ: Vozes, 1996.

PÊCHEUX, M. Análise automática do discurso (AAD-69). In: GADET, F.;

HAK, T. (Org.). Por uma análise automática do discurso. 3. ed. Campinas: Editora da Unicamp, 1997.

SAUSSURE, F. Curso de linguística geral. São Paulo: Editora Cultrix, 1977.

Recebido em 08/11/08. Aprovado em 20/01/09. 